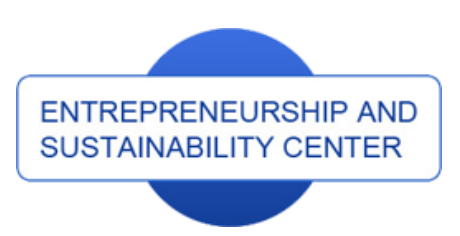

Publisher

http://jssidoi.org/esc/home

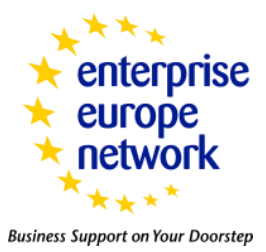

CASPA

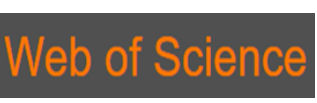

1) Clarivate

\title{
DETERMINANT OF REGIONAL DEVELOPMENT BANK EFFICIENCY FOR THEIR SUSTAINABILITY ISSUES
}

\author{
Sulaeman Rahman Nidar ${ }^{1}$, Mokhamad Anwar ${ }^{2}$, Ratna Komara ${ }^{3}$, \\ Layyinaturrobaniyah ${ }^{4}$
}

1,2,3,4 Padjadjaran University, Jl. Dipati Ukur no. 35 Bandung, Indonesia

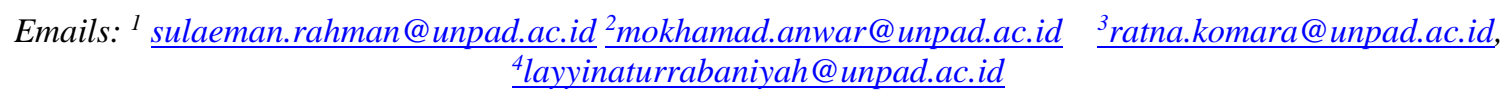

Received 10 December 2019; accepted 15 July 2020; published 30 September 2020

\begin{abstract}
Banking efficiency is the main factor that needs to be considered in creating banking competitiveness. This study aims to determine the efficiency of the Regional Development Banks (RDBs) in Indonesia. There are around 26 RDBs throughout Indonesia, however, due to the completeness of the data as the main criteria of this purposive sampling research, this study includes 19 RDBs in observations. This study adopts a quantitative analysis with multiple regressions. There are only 2 variables that significantly affect efficiency, namely the Operational Cost to Operational Income (OCOI) variable and the Loan to Deposit Ratio (LDR) variable, and the other variables do not have any significant effects on the efficiency. In general, the dependent variable can be explained simultaneously by the independent variables around 95\%, and the remaining 5\% is explained by other variables outside the model. Since only 7 RDBs are efficient, then it is necessary for the management of those banks to do hard effort to maintain efficiency and keep on as sustainable banking in this competitiveness era.
\end{abstract}

Key words: Efficiency; Regional Development Banks; Operational Cost to Operational Income; Loan to Deposit Ratio

Reference to this paper should be made as follows: Nidar, S.R., Anwar, M., Komara, R., Layyinaturrobaniyah. 2020. Determinant of regional development bank efficiency for their sustainability issues. Entrepreneurship and Sustainability Issues, 8(1), 1133-1145. http://doi.org/10.9770/jesi.2020.8.1(76)

JEL: G20, G21, H21

\section{Introduction}

Indonesia has some kinds of commercial banks viewed in terms of ownership, namely Central-GovernmentOwned Banks or State-Owned Banks (SOBs), Provincial-Government-Owned Banks or Regional Development Banks (RDBs), National Private Banks (NPBs), Foreign-Owned Banks (FOBs), and Joint-Venture Banks (JVBs). All kinds of those banks are treated equally by the Indonesia Financial Services Authority (IFSA) or Otoritas Jasa Keuangan $(\mathrm{OJK})$ in terms the compliance with the rules and regulations. 


\section{ENTREPRENEURSHIP AND SUSTAINABILITY ISSUES}

ISSN 2345-0282 (online) http://jssidoi.org/jesi/

2020 Volume 8 Number 1 (September)

http://doi.org/10.9770/jesi.2020.8.1(76)

Regional Development Bank is a commercial bank whose ownership is owned by the Provincial Government in various regions in Indonesia. For instance, PT Bank Pembangunan Daerah Jawa Timur (Bank of Regional Development of East Java Province Co.) or Bank Jatim, is a bank which its share-ownership is owned by the Government of East Java Province. PT Bank Pembangunan Daerah Bali (Bank of Regional Development of Bali Province Co.) or Bank Bali, is a bank which its share-ownership is owned by the Government of Bali Province. Similar to other banks, Regional Development Banks (RDBs) are assessed and evaluated by IFSA or OJK as well as their stakeholders. One of the performance measurements assessed is in terms of their efficiency. Banks which have high-efficiency score are presumed as competitive and thought as in demand by the public.

Bank efficiency at this time is still important in evaluating bank performance. Banks that are classified as efficient usually have good performance, because, with efficient bank management, the bank means that it has used the distribution of resources more efficiently than other banks so that the costs incurred are relatively smaller compared to other banks. If the cost of banking services increases it will cause damage to bank efficiency (Berger et al., 2001).

Measurement of efficiency performance in the banking industry is becoming more widely used by banks and banking regulators in the world, given that competition between banks occurs wider not only in certain regions, in certain countries but also in banks operating across countries. Banks that operate more efficiently are considered capable of winning competition wherever the banks operate. Efficiency can also be related to credit composition, such as for SMEs (Berry, Grant, 2004).

On the other hand, financing is the most familiar word in the financial industry because financing is an activity that will generate income and profits for financial institutions. Financing in the banking industry includes services on two conditions depending on the type of business operation. First, if a bank operates conventionally, financing means loans or credit. Second, if the bank operates by operating Islamic business, then financing means Islamic or Sharia financing, it can be in the form of mudharaba, musyaraka, murabaha, and other forms of financing products. The first uses the term interest-based in the calculation of income for lenders or banks. Thus, interest rates have become the main instrument for banks as a cost for their financing to borrowers. Meanwhile, the latter uses the term profit-sharing or revenue-sharing in the practice of mudharaba and musyaraka financing because the bank provides funds for customers who are considered partners in the business and uses margin provisions for murabaha cases because murabaha schemes are similar to banks that sell fixed assets such as houses, vehicle, etc. Thus, the margin is similar to sales profit.

This research focuses on RDBs' operations which generally operate conventionally so that the intended financing in this study is the provision of bank loans' facilities to its customers. The financing itself can be in the form of productive loans and consumer loans for borrowers.

Indonesia as a country in the category of emerging economies and middle-income countries is currently continuously carrying out economic development in various sectors both driven by the government sector and by the private sector in the hope that economic development can run sustainably (sustainable development) with conducive economic growth.

Research on efficiency is one of the most developed studies in the scope of financial institution management, especially banking today. The thing that underlies the importance of the research is that the financial industry is a highly regulated industry, where industry players must follow and comply with the rules imposed by policymakers (financial services authority) and the success rate of a bank will depend on the quality service (service quality) provided. The Financial Services Authority applies strict and prudent rules because banks manage public 


\section{ENTREPRENEURSHIP AND SUSTAINABILITY ISSUES}

ISSN 2345-0282 (online) http://jssidoi.org/jesi/

2020 Volume 8 Number 1 (September)

http://doi.org/10.9770/jesi.2020.8.1(76)

funds, which of course must be protected, while service quality is important given that all banks have relatively similar products, the difference is the quality of service.

Regional Development Banks are a category of banks that are quite numerous and are expected to decrease, as expected by the OJK because OJK feels that the number of banks in Indonesia is already too much. The number of national commercial banks is 115, and some are expected to join with the ideal number of only 50-70 banks. Therefore, through conducting this efficiency research, it is expected that it can provide a recommendation that there are several regional development banks that can be merged because they do not have good efficiency.

This research focuses on Regional Development Banks (RDBs), which are the spearhead of banking in provinces in Indonesia. The efficiency of research with RDBs objects is still very rarely found so it is hoped that the results of this study can contribute to research.

\section{Theoretical Background}

Theoretically, research on efficiency was initiated by Farel (1957), which was then followed by subsequent researchers from various types of industries. Efficiency research in the banking industry has been conducted by many authors including Fethi et.al (2011), Shin and Kim (2011), Sufian (2010, 2011), Gardener et.al (2011), Kenjegalieva et al. (2009), Yao et al. (2008), Kao and Liu (2004), Drake and Hall (2003), Tvaronavičienè et al., 2018, Firtescu et al. (2019), Siddique et al. (2020). They generally use the financial data of commercial banks in various countries. While efficiency studies with objects of regional government banks are currently rarely conducted.

If we look at it in general terms, RDBs efficiency is part of the company's performance measurement for banking companies. As is known, the performance measure of banking companies can be seen from two sides, namely, financial ratio analysis and frontier analysis. Financial ratio analysis is a measure of financial ratio performance achieved by a bank. Some ratios that are used as a measure of bank company performance include liquidity ratios, capital ratios, problematic financing ratios, profitability ratios, and others.

Meanwhile, to complement the existing analysis, frontier analysis then emerges with a non-parametric and parametric approach to see and compare the efficiency performance of a bank with other banks in the industry. This analysis is very useful for policy-makers in assessing the performance of banks in the industry by looking at which banks operate efficiently and which banks are not yet efficient in their operations. Knowing this, bank supervisors or policy-makers can make treatment to banks that are not yet efficient to improve their performance to be efficient. In addition, the results of this analysis will also benefit the bank's management by taking tactical steps and making plans so that the bank can continue to improve its efficiency.

Efficiency itself can be seen from various types including technical efficiency (technical efficiency), cost efficiency (cost efficiency) and profit efficiency (profit efficiency). Technical efficiency can see how the existing inputs can produce optimal output (output orientation) or with the goal of producing certain outputs, how to use minimal inputs (input orientation). Cost efficiency explains how companies can minimize costs with specific output targets and profit efficiency explains the ability to produce certain profits with minimal costs. This study will use technical efficiency as a basis for estimating its efficiency with a non-parametric approach.

Efficiency with a non-parametric approach is an approach that uses deterministic techniques that calculate how much the level of output productivity and input efficiency that occurs in a company. The deterministic approach can be calculated with a mathematical approach and linear programming. The most popular efficiency calculation technique in the non-parametric approach is the data envelopment analysis (DEA) technique. In addition, the 
parametric approach to efficiency attempts to estimate efficiency based on an econometrics approach that estimates efficiency based on various factors that are thought to influence efficiency.

The concept of efficiency with DEA is closely related to the concept of productivity which is the ratio of the acquisition of output to the input used. Examples of "i" company productivity are as follows:

$$
\text { Ratio }_{i}={ }^{\alpha} y_{i} / \beta_{\beta^{\prime} x_{i}}, i=1, \ldots, N
$$

$\mathrm{y} \_\mathrm{i}$ is a vector of a number of $\mathrm{M}$ outputs and $\mathrm{x} \_\mathrm{i}$ is a vector of a number of $\mathrm{K}$ inputs. Then by entering the weights the function becomes:

$$
\begin{array}{ll}
\text { Maximize } \alpha, \beta: & \alpha^{I} y_{i} / \beta^{I} x_{i} \\
\text { With the condition } & \alpha^{I} y_{s} / \beta^{I} x_{s} \leq 1, s=1, \ldots, N \\
& \alpha_{m} \geq 0, m=1, \ldots \ldots, M \\
& \beta_{k} \geq 0, k=1, \ldots, K
\end{array}
$$

In order to maximize the efficiency of the company with the condition that the efficiency of each company will be around a number less than and equal to one and all weights are non-negative, an optimal weight will be required. With transformation and simplification, the efficiency function becomes:

$$
\begin{array}{ll}
\text { Maximize } \alpha, \beta: \alpha^{I} y_{i} & \\
\text { With the condition } & \beta^{I} x_{i}=1 \\
& \alpha^{I} y_{s}-\beta^{I} x_{s} \leq 0, s=1, \ldots, N \\
& \alpha \geq 0 \\
& \beta \geq 0
\end{array}
$$

and for minimum functions:

$$
\begin{array}{ll}
\text { Minimize: } & \theta_{i}, \lambda: \theta_{i} \\
\text { With the condition } & \sum_{s} \lambda_{s} y_{s}-y_{i} \geq 0 \\
& \theta_{i} x_{i}-\sum \lambda_{s} x_{s} \geq 0 \\
& \lambda_{s} \geq 0
\end{array}
$$

Where $\theta_{i}$ is a technical efficiency score with input orientation for company i.

$$
T E_{I N P U T, i}=\theta_{i}
$$

The measure states the ability of a company to reduce inputs assuming the same output, relative to other companies. In this way companies will get a score of 1 as efficient companies. In addition, companies that score less than one $\left(\theta \_i \leq 1.0\right)$ are companies that are not yet efficient.

In addition to the input orientation as above, there is also efficiency with the output orientation. This second type of efficiency considers that the company can obtain greater output by using the same input. Companies that obtain optimal output are efficient companies. 


\section{ENTREPRENEURSHIP AND SUSTAINABILITY ISSUES}

ISSN 2345-0282 (online) http://jssidoi.org/jesi/

2020 Volume 8 Number 1 (September)

http://doi.org/10.9770/jesi.2020.8.1(76)

In estimating the efficiency value of a RDBs, we need to determine what approach is used in selecting inputs and outputs. There are two of the most popular approaches, namely the production approach and the intermediation approach. The production approach treats RDBs the same as other industries that produce goods or services so that it sees raw materials, capital and human resources as production factors to produce output. This approach usually uses general \& administrative costs, labor costs and capital costs as input and makes the total loans received, total financing / financing receivables as output. While the intermediation approach sees the RDBs as an intermediary institution (financial intermediary) between the requester and the recipient of the financing so that it is different to place the loan received as an input as well as other resources used. Banking can be applied to a large range of financial institutions, Hafferman (2005). Banks as intermediary institutions are needed in financing, Gitman and Zutter (2012). Usually financing, equity, income can be used as output. This research will use an intermediation approach as a determinant of its input and output.

\section{Research Objective and Methodology}

Research is a systematic study; complete efforts are needed to be carried out sequentially, starting with the disclosure of the problems presented in the introduction. Then, it is necessary to submit a literature review and research method. The research method used in this research is descriptive verification. That is, the research will be preceded by an explanation of the findings that reveal the facts of the variable under study and verification of the resulting model.

This study uses RDBs as units of analyses covering a number of 26 RDBs throughout Indonesia. Thus, the study population is 26 RDBs. However, the sample members are 19 RDBs. These 19 RDBs are obtained based on the purposive sampling method with certain criteria, namely the RDBs used as included sample are only RDBs that have complete data from 2012 to 2017.

The analysis tool is done by using multiple regression, namely by using generalized least squares (GLS) regression analysis. The selection of predetermined variables is Capital Adequacy Ratio (CAR), Non-Performing Loans (NPL), Return on Assets (ROA), Operating Costs to Operating Revenue (OCOI), Loans to Deposits Ratio (LDR), Capital, and Asset. The variables are chosen based on studies from previous researchers, to determine efficiency performance.

The analysis is carried out in two stages. First, calculating the efficiency of RDBs by using the Frontier Efficiency approach, namely with the Data Envelopment Analysis (DEA) approach, and Second, creating a model that connects efficiency with banking characteristic variables. The basis for selecting a non-parametric DEA method for the following reasons: this method does not require certain distribution assumptions in data processing, data processing is simpler, and this method is suitable for small samples. Then, multiple regression analysis is used as a tool to form efficiency determinant models.

\section{Result and Discussion}

\subsection{Descriptive Analysis of RDBS Efficiency in Indonesia}

Indonesia has a form of financial institutions consisting of two forms, namely bank financial institutions and nonbank financial institutions. Bank financial institutions consist of central banks, commercial banks, and people's credit banks. Commercial banks are divided into several groups, namely national private commercial banks, stateowned banks, and regional development banks. The character of private commercial banks is different, from stateowned banks, and also different from regional development banks. 
The total number of banks in Indonesia is 115 banks, which are divided into 4 groups of commercial bank business activities based on the number of assets owned by banks. Due to competition with a large number of banks, there are many inefficient banks and as a result, the market share becomes smaller and costs become higher or banks become inefficient. The decrease in margins is related to the relaxation of competition conditions, and can cause inefficiency. Moudos and De Guovara (2004). Theoretical and empirical literature on bank margins has dealt solely with interest margins (Valverde, Fernandes, 2007).

Of the 26 RDBs studied, several descriptive explanations regarding RDBs efficiency have been obtained, and 19 RDBs can be presented below. Development of RDBs in 19 Provinces from 2012 to 2017, in terms of efficiency, there are 7 stable RDBs, and there are also banks that experience unstable or fluctuating efficiency of 6 RDBs.

There are a number of RDBs that during the study are considered inefficient, that is, as many as 6 RDBs. RDBs that experience inefficiency is $30 \%$ of the total 19 RDBs studied, and this shows that there needs to be attention from managers, and owners, so they try to make improvements, with improvements in good governance. As a bank owned by the provincial government, efficiency in management is important. The Provincial Government as the owner is responsible for steps to make it healthy, and sustainable, such as increasing the number of factors that cause inefficiency, Operational Cost to Operating Income (OCOI) of RDBs that is high enough to be one of the causes of bank inefficiency should be reviewed operational costs and operating income. Government ability has negatively affected bank efficiency while economic growth will not affect bank efficiency (Nguyen, Dau, 2020).

The following are detailed categories of the results of the description and RDBs names grouped according to their efficiency (Figure 1):

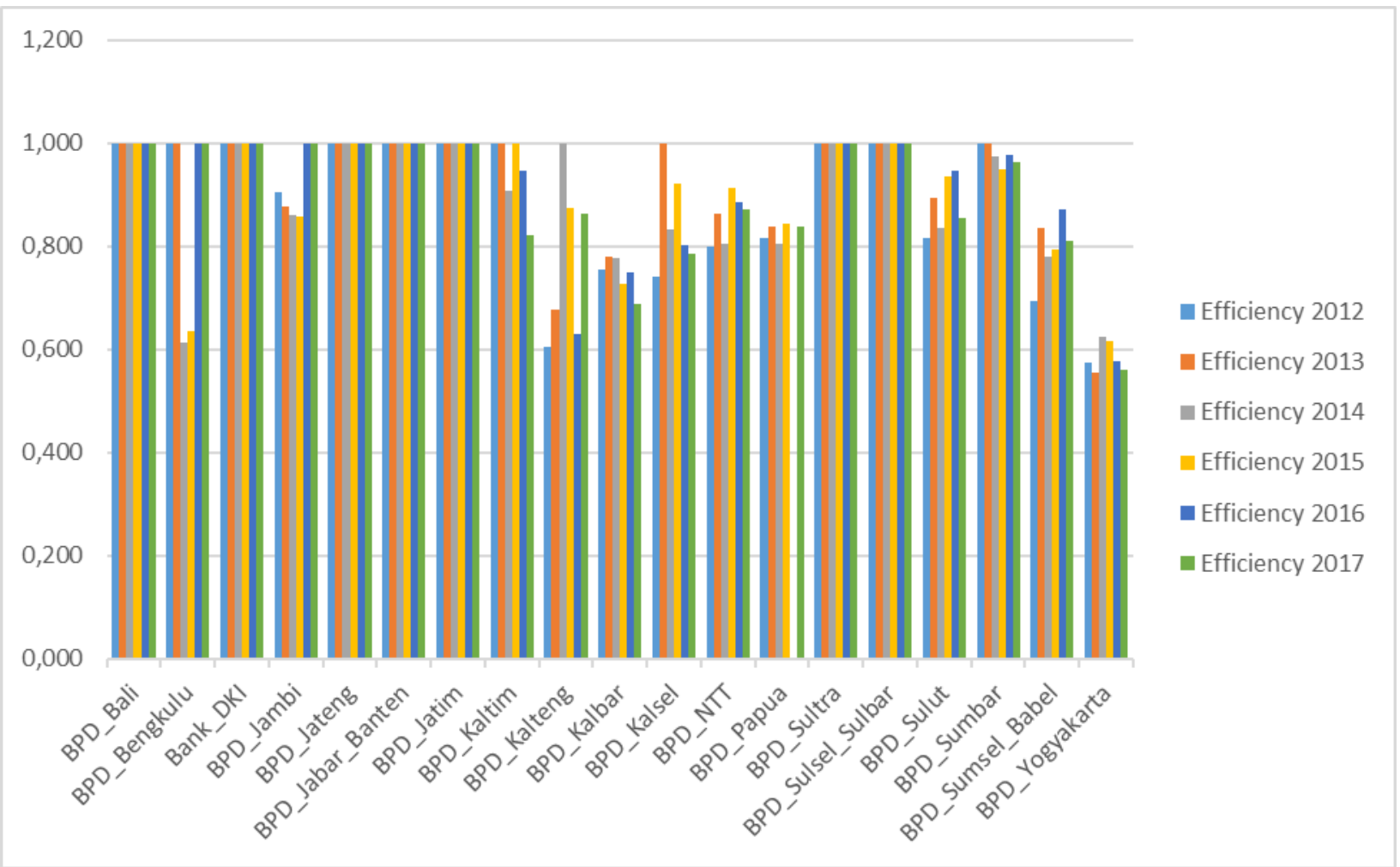

Figure 1. Graph of Development of RDBs Efficiency Levels in 19 Provinces in Indonesia in 2012-2017. Source: processed data 
It is explained from the table above, that there are RDBs that experience a stable level of efficiency, namely RDB Bali, RDB DKI, RDB Jateng, RDB Jabar Banten, RDB Jatim, RDB Sultra and RDB Sulsel-Sulbar. Whereas some RDBs experience fluctuations but returned to efficiency in the last year are RDB Bengkulu, and RDB Jambi. RDBs which experience an efficient level in one year, but tends to be inefficient is RDB Kalimantan Tengah.

RDBs that experience a decrease in the level of efficiency were, RDB Kaltim, RDB Kalsel and RDB Sumbar. Inefficient RDBSs are RDB Kalbar, RDB NTT, RDB Papua, RDB Sulut, RDB Babel Sumsel, RDB Yogyakarta. The lowest level of efficiency was at RDB Yogyakarta in 2013 with an efficiency value of 0.556229 . Descriptively, below is the result of processing descriptive statistics as follows (Table 1):

Table 1. Descriptive Statistic of 19 RDBs

\begin{tabular}{|c|c|c|c|c|c|c|c|c|c|}
\hline & $\begin{array}{l}\text { Total Equity } \\
\text { (IDR Billion) }\end{array}$ & $\begin{array}{c}\text { Total Asset } \\
\text { (IDR Billion) }\end{array}$ & ROA & ROE & CAR & LDR & NPL & $\begin{array}{c}\text { Efficien } \\
\text { cy } \\
\text { Score } \\
\end{array}$ & OCOI \\
\hline Max & $10,104.97$ & $114,980.17$ & 0.052 & 0.399 & 0.384 & 1.194 & 0.0565 & 1.000 & 0.980 \\
\hline Min & 283.03 & $2,778.92$ & -0.006 & -0.081 & 0.123 & 0.558 & 0.0003 & 0.000 & 0.280 \\
\hline Average & $2,495.51$ & $20,315.73$ & 0.029 & 0.219 & 0.209 & 0.918 & 0.014 & 0.889 & 0.725 \\
\hline St.Dev & $2,164.50$ & $20,367.62$ & 0.0093 & 0.0747 & 0.0508 & 0.1199 & 0.0141 & 0.1542 & 0.1269 \\
\hline \multicolumn{10}{|c|}{ Description: } \\
\hline $\operatorname{Max}$ & $\begin{array}{l}\text { Jabar_Banten } \\
\text { Bank } 2017\end{array}$ & $\begin{array}{l}\text { Jabar_Banten } \\
\text { Bank } 2017\end{array}$ & $\begin{array}{l}\text { RDB_ } \\
\text { Sultra } \\
2012 \\
\end{array}$ & $\begin{array}{l}\text { RDB_- } \\
\text { Sulut } \\
2012 \\
\end{array}$ & $\begin{array}{l}\text { RDB } \\
\text { Sulsel_Sulb } \\
\text { ar } 2014\end{array}$ & $\begin{array}{l}\text { RDB_Sul } \\
\text { sel_Sulbar } \\
2017\end{array}$ & $\begin{array}{l}\text { RDB_} \\
\text { Kalsel } \\
2017 \\
\end{array}$ & & $\begin{array}{l}\text { Bank } \\
\text { Jateng } \\
2015 \\
\end{array}$ \\
\hline Min & $\begin{array}{l}\text { RDB_Bengkulu } \\
2012\end{array}$ & $\begin{array}{l}\text { RDB_Bengkul } \\
\text { u } 2012\end{array}$ & $\begin{array}{l}\text { RDB_ } \\
\text { Papua } \\
2016\end{array}$ & $\begin{array}{l}\text { RDB_ } \\
\text { Papua } \\
2016\end{array}$ & $\begin{array}{l}\text { Bank_DKI } \\
2012\end{array}$ & $\begin{array}{l}\text { RDB_ } \\
\text { Kalsel } \\
2012\end{array}$ & $\begin{array}{l}\text { RDB_Be } \\
\text { ngkulu } \\
2012 \\
\end{array}$ & & $\begin{array}{l}\text { RDB_Ka } \\
\text { lsel } 2012\end{array}$ \\
\hline
\end{tabular}

Some banking characteristic variables show that the variable that shows a good improvement is the CAR variable, where this ratio has exceeded the provisions of the regulator or OJK, which is above $12 \%$, and indeed it turns out that the average RDBs has a CAR above $12 \%$. Other variables that are quite good are ROA and ROE which have an average of $2.9 \%$ and $2.19 \%$ respectively. meanwhile, the average OCOI is $72.5 \%$, although there are certain RDBs that are still high, especially those that reach OCOI $98 \%$.

\subsection{Analysis of Factors Affecting the Efficiency and Sustainability of RDBs in Indonesia}

Efficiency and Sustainability of banks are important to note, efficiency concerns the ability of banks to manage the resources of banks, while sustainability is related to the ability of banks to be able to compete and adapt (Infobank 2016). Below will be discussed what factors cause a bank is said to be efficient. The regression model explains the dependent variable, namely RDBs' efficiency (Y) and independent variables, namely Capital Adequacy Ratio (CAR), Non-Performing Loans (NPL), Return on Assets (ROA), Operating Cost to Operating Income (OCOI), Loans to Deposits Ratio (LDR), Total Equity (TE), and Total Assets (TA).

Regression Model and Analysis

$\mathbf{Y}_{i t}=a_{i t}+$ CAR $x_{1 i t}+$ NPL $x_{2 i t}+$ ROA $x_{3 i t}+$ OCOI $x_{4 i t}+\operatorname{LDR} x_{5 i t}+$ TE $x_{6 i t}+$ TA $x_{7 i t}+e_{i t}$

Note:

$\mathrm{Y}_{\mathrm{it}}=$ Efficiency

$\mathrm{a}_{\mathrm{it}}=$ Constanta 
$\mathrm{X}_{\mathrm{nit}}=$ Regression Coefficient

e $=$ error

Where:

The Dependent Variable is RDBs' efficiency (Y) which is obtained by the estimation by Data Envelopment Analysis approach.

Meanwhile, the Independent Variables are composed of some variables, namely: Capital Adequacy Ratio (CAR) which reflects the adequacy of capital provided by the owner(s) of the banks. It is measured by the Bank Capital divided by Risk-Based Assets. Non-Performing Loans (NPL) which reflects the problem loans. It is measured by total problem loans to total loans. Return on Assets (ROA), is generated by the ratio of total profit to total assets. This ratio indicates the bank profitability. Operating Cost to Operating Income (OCOI), is calculated by dividing total operating costs to the total operating income of the bank. It is reflected the cost efficiency usage. Loans to Deposits Ratio (LDR) is the proxy for the level of aggressivity of the loan expansion and the liquidity of a bank. The ratio can be generated by dividing the total loans on total deposits. Total Equity is generated by the natural logarithm of Total Equity, and Total Assets are generated by the natural logarithm of Total Assets.

By using a regression analyst with generalized least squares (GLS) regression method, we get:

Table 2. Regression Results between Bank Characteristics Variables and Efficiency

\begin{tabular}{|c|c|c|}
\hline Variable & Coefficient & Prob. \\
\hline $\mathbf{C}$ & 0.077565 & 0.8197 \\
\hline CAR? & -0.251995 & 0.1195 \\
\hline NPL? & -0.916924 & 0.1588 \\
\hline ROA? & 0.126302 & 0.8714 \\
\hline ROE? & 0.150548 & 0.1914 \\
\hline OCOI? & -0.136476 & 0.0007 \\
\hline LDR? & 0.090688 & 0.0035 \\
\hline LOG(TE?) & 0.033431 & 0.2426 \\
\hline LOG(TA?) & -0.002883 & 0.8921 \\
\hline R-squared & 0.953844 & \\
\hline Adjusted R-squared & 0.940051 & \\
\hline
\end{tabular}

Note: Capital Adequacy Ratio (CAR), Non-Performing Loans (NPL), Return on Assets (ROA), Return on Equity (ROE), ratio Operational cost and Operational income (OCOI), Loans to Deposits Ratio (LDR), Natural Logarithm of Total Equity (LOG(TE)), Natural Logarithm of Total Assets (LOG(TA)).

Source: Processed Data

Based on the above results it can be said that:

a. if all coefficients of the independent variable are zero (0) then the dependent variable is 0.077 assuming the cateris-paribus assumption.

b. There are only 2 variables that significantly affect efficiency, namely the OCOI variable and the LDR variable, and the other variables do not have a significant effect on the efficiency variable

c. Each change in the independent variable (OCOI) by 1 unit will reduce the dependent variable by 0.136476 units assuming cateris-paribus. Each change in the independent variable (LDR) by 1 unit will increase the dependent variable by 0.090688 units assuming the ceteris paribus assumption 


\section{ENTREPRENEURSHIP AND SUSTAINABILITY ISSUES}

ISSN 2345-0282 (online) http://jssidoi.org/jesi/

2020 Volume 8 Number 1 (September)

http://doi.org/10.9770/jesi.2020.8.1(76)

d. In general, the dependent variable can be explained simultaneously by independent variables of $95 \%$, and the remaining of $5 \%$ is explained by other variables outside the model.

Viewed on the model:

$\mathrm{Y}=0.077565-0.251995 \mathrm{CAR}-0.916924 \mathrm{NPL}+0.126302 \mathrm{ROA}+0.150548 \mathrm{ROE}$

$-0.136476 \mathrm{OCOI}^{* * *}+0.090688 \mathrm{LDR}^{* * *}+0.033431 \mathrm{TE}-0.002883 \mathrm{TA}$

Note: $* * *$ Significant in $1 \%$.

The model clearly shows the relationship between independent and dependent variables that as a whole indicate conformity with the theory relating to banking operations. CAR should have a positive relationship with efficiency, where the better the capital, the high the CAR will increase efficiency. In the equation above, a negative relationship can be seen, in this case showing that CAR in RDBs is already high, so with a high CAR because capital costs are higher than public funds (deposits) then it becomes a burden for achieving efficiency, in other words RDBs can utilize assets owned to be optimized to achieve better efficiency.

The higher NPL will reduce the level of banking efficiency, this is indicated by a negative sign on the coefficient in the model equation. With high NPLs, bank operational costs have increased from monitoring and collection (collection) of problem loans. In addition, with a high NPL, the potential for banks to expand credit will be hampered even though credit is the main asset that generates earning assets. RDBS must be careful with NPL problems, because high NPLs show RDBS's failure in effectiveness and efficiency in credit management.

The higher NPL will reduce the level of banking efficiency, this is indicated by a negative sign on the coefficient in the model equation. With high NPL, bank operational costs have increased from monitoring and collection (collection) of problem loans. In addition, with a high NPL, the potential for banks to expand credit will be hampered even though credit is the main asset that generates earning assets. RDBs must be careful with NPL problems because high NPL shows RDBs's failure in effectiveness and efficiency in credit management. NonPerforming Loan, significantly affected profitability bank of Return on Equity (Sofie et al., 2020).

The profitability factor shows a positive sign on the variable ROA and ROE. This means that increased ROA and ROE will cause RDBs efficiency to increase. Profitability bank can increase efficiency (Kamarudin et al., 2019). With an increase in profitability, the bank will be able to increase its various activities both its main activity in the form of lending and increase in other bank services that will generate income from services (fee-based income). Improvements in credit management that will improve management and increase income through non-credit such as fee-based income, can increase the level of RDBs efficiency. While research conducted banks in China, The Capital Ratio is positively related to ROA, but negatively related to ROE (Qianqian, Lee 2020). European banks succeed in increasing their profitability despite a compression of their net interest income (Campmas, 2020).

OCOI has a negative coefficient sign, indicating that a high OCOI will cause a decrease in RDBs efficiency. RDBs can improve efficiency by lowering costs and increasing bank revenue. Activities that will reduce costs must be carried out and implemented as quickly as possible, and activities that will increase revenue must also be carried out as soon as possible by the RDBs, so that the RDBs has high efficiency, and has good competitiveness.

The Total Equity Factor (TE) has a sign of a positive coefficient that is different from the Total Assets (TA), this can indicate that the own capital from RDBs is still too little to be included. In contrast to Total Assets where TA has a negative sign. Total assets can be an indication for bank size, the higher the total assets will have an effect on bank profitability. Significant negative influence of bank size to profitability is found on models of Vietnam 


\section{ENTREPRENEURSHIP AND SUSTAINABILITY ISSUES}

ISSN 2345-0282 (online) http://jssidoi.org/jesi/

2020 Volume 8 Number 1 (September)

http://doi.org/10.9770/jesi.2020.8.1(76)

and Thailand and no significant effect on the model of Malaysia (Thi et al., 2020). This shows that the RDBs must quickly add its own capital, through the addition of the Provincial and Regency / City Governments to increase its placement capital so that efficiency increases due to the ability of the RDBs to increase due to increased capital.

While the efficiency of the Total Assets needs to be considered, where the sign of the coefficient is negative, this shows that the RDBs must be able to optimize its assets, so that the income of the RDBs increases. Increase of asset will increase of return (Ametefe et al., 2011). A negative sign indicates that at this time, assets owned by RDBs should be able to increase efficiency but instead actually reduce efficiency. In other words, RDBs in Indonesia have not been able to take advantage of the concept of economies of scale where when assets grow, the unity of operational costs will decrease which will ultimately increase efficiency. In the case of this RDBS concept was not proven.

RDBs technical efficiency performance has not reached the optimal efficiency level of 100 percent. While the analysis is based on asset groups, on average, large-scale RDBs are more efficient than medium and small-scale RDBS. If a large commercial bank with a low performance will cause a decrease in the quality of the loan portfolio (Miller, Naulas, 2010). Consolidation is sweeping the banking industry (Strahan, Weston, 1998). This research has important implications in order to optimize efficiency performance so that small and medium banks must merge and improve the banking intermediary function (Abidin, Endri, 2009). Attention to the competitive environment and corporate strategy will be able to maintain sustainability in performance, Hoque and Chia (2012).

The results of this study support the ongoing efforts made by the regulator to recommend mergers with banks, especially small and medium-scale banks. Banks that often merge are between several small banks (Peek, Rosengren, 1998). One of the concerns of regulators is the effect of small bank consolidation, namely on capital access and cost of capital (Scott, Dunkelberg, 2003). Other research shows that the efficiency rate of RDBS in Indonesia is in average $93.2 \%$. A total of 12 banks from 26 RDBS throughout Indonesia have achieved 100\% efficiency. While 14 other RDBs are not efficient $(<100 \%)$ in carrying out their operations. Central Java Bank is the RDBS which has the lowest efficiency level of $78.6 \%$. Interest expense is the cause of the most inefficient RDBs.

\section{Conclusions}

Some points that can be concluded in the results of the discussion above are as follows:

1. The efficiency of the RDBs shows a good direction, although in the midst of quite sharp banking competition.

2. Improvements to several ratios will further increase the efficiency to be achieved by RDBs. As two variables that provide a significant influence on the resulting model equation, namely LDR and OCOI. While another thing is the direction of the coefficient of several factors also need to be considered, such as CAR, and TA. With the implication that RDBS needs to increase their own capital.

Based on these results, there are several suggestions and recommendations for several related parties including:

1. For the management of RDBs banks, it is suggested that it is possible to pay attention to a number of internal factors that can improve bank efficiency performance including LDR and OCOI which are proven to be able to influence efficiency performance. By increasing the LDR and reducing the OCOI, it was proven to be able to improve the efficiency of RDBs.

2. For policymakers, in this case, the Financial Services Authority (OJK), it is recommended that it is possible to produce policies that are conducive to supporting the performance of banks in Indonesia, especially for RDBs. Some recommendations related to the results of this study are, the policy calls for credit expansion while still taking into account the level of collectability in accordance with a significant 


\section{ENTREPRENEURSHIP AND SUSTAINABILITY ISSUES}

ISSN 2345-0282 (online) http://jssidoi.org/jesi/ 2020 Volume 8 Number 1 (September)

http://doi.org/10.9770/jesi.2020.8.1(76)

positive relationship between LDR with efficiency and a negative relationship between NPL and efficiency.

3. For local governments as the main owners of RDBs, especially for banks whose equity capital is still low so as to increase their capital according to the positive relationship between capital and efficiency to a certain extent so that the CAR has been optimal, because if the CAR has passed the optimal limit, then it will reduce efficiency.

4. For the next researcher, it is expected to add data completeness for all RDBs in Indonesia by completing the data directly from the financial statements of these banks in addition to the Financial Services Authority.

\section{References:}

Abidin, Zaenal, Endri Endri. 2009. Kinerja Efisiensi Teknis Bank Pembangunan Daerah: Pendekatan Data Envelopment Analysis (DEA), Surabaya Jurnal Akuntansi dan Keuangan, 11(1) https://doi.org/10.9744/jak.11.1.pp.\%2021-29

Ametefe, F., Aboagye, A.Q.Q., Kuman-Koma, E. Sarpong, 2011. Housing and Contraction Finance, Deposit obligation, and Bank Performance in Ghana. Journal of Property Research, 28(2), 151-165. https://doi.org/10.1080/09599916.2010.538478

Berger, Allen N., Klapper, Leora F., Udell, Gregory F. 2001. The Ability of Banks to Lend to Informationally Opaque Small Businesses. Journal of Banking \& Finance, 25, 2127-2167. https://doi.org/10.1596/1813-9450-2656

Berry, Aidan, Grant, Paul, 2004. European Bank Lending to the UK SME Sector. International Small Business Journal, 22(2), 115-130. https://doi.org/10.1177/0266242604041310

Campmas, A. 2020. How do European banks portray the effect of policy interest rates and prudential behavior on profitability? Research in International Business and Finance, 50. https://doi.org/10.1016/j.ribaf.2018.09.001

Drake, L., Hall, M.J.B. 2003. Efficiency in Japanese Banking: An empirical analysis. Journal of Banking \& Finance, 27, 891-917. https://doi.org/10.1016/S0378-4266(02)00240-6

Fethi, M.D., Shaban, M., Jones, T. W. 2011. Liberalisation, Privatisation, and the Productivity of Egyptian Banks: A Non-Parametric Approach. The Service Industries Journal, 31(7), 1143-1163. https://doi.org/10.1080/02642060903431686

Firtescu, B.N., Terinte, P.-A., Roman, A., Anton, S.G. 2019. Corporate Governance and Bank Profitability. An Empirical Assessment for Emerging Europe. Transformations in Business \& Economics, 18, (2A(47A)), 531-552.

Gardener, E., Molyneux, P., Nguyen-Linh, Hoai. 2011. Determinants of efficiency in South East Asian Banking. The Service Industries Journal 31(16), 2693-2719.

Gitman, Lawrence J., Zutter, Chad J. 2012. Principles of managerial finance 13th Ed. The Prentice Hall series in finance.

Hoque, Zahiru, Chia, Maybelle. 2012. Competitive Forces and the Levers of Control Framework in a Manufacturing Setting. Qualitative Research in Accounting \& Management, 9(2), 123-145. Emerald Group Publishing Limited.

Infobank Magazine, Issue April 2016.

Kamarudin, F., Sufian, F., Aina, N., Anwar, M., Hussain, H. I. 2019. Bank Efficiency in Malaysia a DEA Approach. Journal of Central Banking Theory and Practice, 71(595), 133-162. https://doi.org/10.2478/jcbtp-2019-0007

Kao, C., Liu, S.T. 2004. Predicting Bank Performance with Financial Forecasts: A Case of Taiwan Commercial Banks. Journal of Banking \& Finance, 28, 2353-2368. https://doi.org/10.1016/j.jbankfin.2003.09.008

Kenjegalieva, K.A., Simper, R., Jones, T.G.W. 2009. Efficiency of Transition Banks: Inter-country Banking Industry Trends. Applied Financial Economics, 19, 1531-1546. 


\section{ENTREPRENEURSHIP AND SUSTAINABILITY ISSUES}

ISSN 2345-0282 (online) http://jssidoi.org/jesi/ 2020 Volume 8 Number 1 (September) http://doi.org/10.9770/jesi.2020.8.1(76)

Miller, Stephen M., Noulas, Athanasios G. 1997. Portfolio Mix and Large-Bank Profitability in the USA. Applied Economics, 29(4), 505512.

Nguyen, V. C., Dau, T. 2020. Government Ability, Bank-Specific Factors and Profitability: An Insight from Banking Sector of Vietnam. JARDCS, 12(4), 415-424. https://doi.org/10.5373/JARDCS/V12I4/20201455

Peek, Joe, Rosengren, Eric S. 1998. Bank Consolidation and Small Business Lending: It's not just Bank Size that Matters. Journal of Banking \& Finance, 22, 799-819

Qianqian, Hu, Lee, Sang Whi. 2020. The Determinan of Bank Profitability: Evidence from Listed Banks in China. Internatioan Commerce and Information Review, 22(1), 173-187.

Scott, Jonathan A., Dunkelberg, William C. 2003. Bank Mergers and Small Firm Financing. Journal of Money, Credit and Banking, 35(6), 999-1017.

Shin, D.J., Kim, B.H.S. 2011. Efficiency of the Banking Industry Structure in Korea. Asian Economic Journal, 25(4), 355-373. https://doi.org/10.1111/j.1467-8381.2011.02066.x

Siddique, A., Masood, O., Javaria, K., Huy, D.T.N. 2020. A comparative study of performance of commercial banks in ASIAN developing and developed countries. Insights into Regional Development, 2(2), 580-591. https://doi.org/10.9770/IRD.2020.2.2(6)

Sofie, M., Hasan, A., Manurung, A.H. 2020. Determinants of Bank Profitability with Size as Moderating Variable. Journal of Applied Finance \& Banking, 10(1), 153-166 Scientific Press International Limited.

Strahan, Philip E., Weston, James, P. 1998. Small Business Lending and the Changing Structure of the Banking In-dustry. Journal of Banking \& Finance, 22, 821-845.

Sufian, F. 2010. The Impact of the Asian Financial Crisis on Bank Efficiency: the 1997 Experience of Malaysia and Thailand. Journal of International Development, 22, 866-889. https://doi.org/10.1002/jid.1589

Sufian, F. 2011. Benchmarking the Efficiency of the Korean Banking Sector: a DEA Approach. Benchmarking. An International Journal, $18(1), 107-127$.

Thi, B., Dao, T., Nguyen, D.P. 2020. Determinants of Profitability in Commercial Banks in Vietnam, Malaysia and Thailand. Journal of Asian Finance Economics and Business, 7(4), 133-143. https://doi.org/10.13106/jafeb.2020.vol7

Tvaronavičienė, M., Masood, O., Javaria, K. 2018. Preconditions of the Eurozone economic security: how to overcome liquidity risk and cost inefficiency in leading banks of UK and Germany. Polish journal of management studies, 18(1), $418-427$. https://doi.org/10.17512/pims.2018.18.1.31

Valverde, Santiago C., Fernandez, Francisco R. 2007. The Determinants of Bank Margins in European Banking. Journal of Banking \& Finance, 31, 2043-2063.

Yao, S., Han, Z., Feng, G. 2008. Ownership Reform, Foreign Competition and Efficiency of Chinese Commercial Banks: A NonParametric Approach. The World Economy, 1310-1326. https://doi.org/10.1111/j.1467-9701.2008.01130.x 


\section{ENTREPRENEURSHIP AND SUSTAINABILITY ISSUES}

ISSN 2345-0282 (online) http://jssidoi.org/jesi/ 2020 Volume 8 Number 1 (September) http://doi.org/10.9770/jesi.2020.8.1(76)

Sulaeman Rahman NIDAR is an Associate Professor in Finance, Faculty of Economics and Business of Padjadjaran University, Indonesia. His research area interest is on Corporate Finance, Microfinance, Banking and Financial Literacy.

ORCID ID: https://orcid.org/0000-0002-9780-2012

Mokhamad ANWAR is Associate Professor in Finance, Faculty of Economics and Business of Padjadjaran University, Indonesia. His area of research interest and focus is Corporate Finance, Banking, and Risk Management.

ORCID ID: https://orcid.org/0000-0003-2641-7667

Ratna KOMARA is serves as a lecturer associated with the Faculty of Economics and Business of Padjadjaran University, Indonesia. Her area of research interest and focus is Corporate Finance, Banking, and Risk Management.

ORCID ID: https://orcid.org/0000-0002-0209-1095

LAYYINATURROBANIYAH serves as a lecturer associated with the Faculty of Economics and Business of Padjadjaran University, Indonesia. Her area of research interest and focus is Corporate Finance, Financial Literacy, and Risk Management.

ORCID ID: https://orcid.org/0000-0002-3407-1160

Make your research more visible, join the Twitter account of ENTREPRENEURSHIP AND SUSTAINABILITY ISSUES:

@Entrepr69728810

Copyright (C) 2020 by author(s) and VsI Entrepreneurship and Sustainability Center

This work is licensed under the Creative Commons Attribution International License (CC BY).

http://creativecommons.org/licenses/by/4.0/

(C) (†) Open Access 